\title{
Peningkatan Kemampuan Motorik Kasar Anak melalui Permainan "Finding A Star" pada Kelompok A di TK PGRI 03 Tumpang
}

\author{
Nevasheza Argaputri*, Retno Tri Wulandari, Wuri Astuti \\ Universitas Negeri Malang, Jl. Semarang No. 5 Malang, Jawa Timur, Indonesia \\ *Penulis korespondensi, Surel: sheza08.sp@gmail.com
}

Paper received: 2-2-2021; revised: 20-2-2021; accepted: 27-2-2021

\begin{abstract}
The purpose of the research is to describe the application of Finding A Star to improve the rough motor skills of early childhood in group A in TK PGRI 03 overlap and describe the increase in the rough motor skills of child group A in TK PGRI 03 through the game Finding A Star. The research plan used is a class action research (CAR). The study was conducted over two cycles, each of which was performed twice as much as a meeting consisting of planning, implementing, observation, and reflection. The data collection techniques used are observations, interviews, and documentation. The analysis of the data used is qualitative and quantitative. Improvement a the child's rough motor ability from the preset to the implementation of cycle II with a strength indicator increases with a percentage of 62.5 percent, Agility increases with a percentage of 87.5 percent flexibility increases with a percentage of 62.5 percent accuracy increases with a percentage of 75 percent the balance increases with a percentage of 75 percent. Based on the results of the performance of Finding A Star game that the child's rough motor skills proved increased
\end{abstract}

Keywords: rough motor; game Finding A Star; children aged 4-5 years

\begin{abstract}
Abstrak
Tujuan penelitian adalah mendeskripsikan penerapan permainan Finding A Star untuk meningkatkan kemampuan motorik kasar anak usia dini pada kelompok A di TK PGRI 03 Tumpang dan mendeskripsikan peningkatan kemampuan motorik kasar anak kelompok A di TK PGRI 03 Tumpang melalui permainan Finding A Star. Rancangan penelitian yang digunakan merupakan penelitian tindakan kelas (PTK). Penelitian ini dilakukan selama dua siklus, setiap siklusnya dilakukan sebanyak dua kali pertemuan yang terdiri dari perencanaan, pelaksanaan, pengamatan, dan refleksi. Teknik pengumpulan data yang digunakan adalah observasi, wawancara, dan dokumentasi. Analisis data yang digunakan adalah kualitatif dan kuantitatif. Peningkatan kemampuan motorik kasar anak dari pratindakan sampai pelaksanaan siklus II dengan indikator kekuatan meningkat dengan presentase 62,5 persen, kelincahan meningkat dengan presentase 87,5 persen, kelentukan meningkat dengan presentase 62,5 persen, ketepatan meningkat dengan presentase 75 persen, keseimbangan meningkat dengan presentase 75 persen. Berdasarkan pemamparan hasil pelaksanaan permainan Finding A Star bahwa kemampuan motorik kasar anak terbukti meningkat.
\end{abstract}

Kata kunci: motorik kasar; permainan Finding A Star; anak usia 4-5 tahun

\section{Pendahuluan}

Perkembangan motorik dapat diartikan sebagai perkembangan pengendalian gerak jasmani melalui kegiatan pusat syaraf, urat syaraf, dan otot terkoordinasi (Hurlock, 1978:150). Berdasarkan Permendikbud No.137 Tahun 2014 tentang Standar Nasional Pendidikan Anak Usia Dini tentang tingkat pencapaian motorik kasar anak usia 4-5 tahun antara lain, menirukan gerakan binatang; pohon tertiup angin ataupun pesawat terbang; melakukan gerakan menggantung; melakukan gerakan melompat, meloncat, dan berlari secara terkoordinasi; melempar sesuatu secara terarah; menangkap sesuatu secara tepat; melakukan gerakan antisipasi; menendang sesuatu secara terarah, h) memanfaatkan alat permainan diluar kelas. 
Berdasarkan observasi pada bulan Januari dikelompok A di TK PGRI 03 Tumpang, ditemukan bahwa aspek perkembangan motorik kasar anak masih belum berkembang secara optimal. Dari hasil pengamatan yang dilakukan di TK PGRI 03 Tumpang terdapat permasalahan dalam aspek kemampuan motorik kasar dari jumlah keseluruhan terdapat 8 anak, ada 6 anak yang belum optimal dalam unsur kekuatan, kelentukan, ketepatan, ada 5 anak yang belum optimal dalam unsur kelincahan dan keseimbangan. Adapun beberapa faktor yang mempengaruhi perkembangan motorik kasar anak yaitu: a) sistem syaraf (Heri Rahayubi, 2012: 225), bahwa sistem syaraf sangatlah berpengaruh dalam perkembangan motorik karena sistem saraflah yang mengontrol aktivitas motorik pada tubuh manusia; b) usia (Sumantri, 2005:112), usia berpengaruh terhadap kesiapan dan kemampuan untuk mempelajari dan menampilkan tugas tertentu; c) kondisi fisik (Heri Rahyubi, 2012: 225), perkembangan motorik kasar sangat erat kaitannya dengan kondisi fisik seseorang; d) lingkungan (Bambang Sujiono (2008: 3.28), lingkungan mempengaruhi perkembangan motorik kasar, hal ini dikarenakan adanya stimulasi dari lingkungan, misalnya sarana dan prasarana yang menarik maka anak akan bergerak menuju ke arah benda tersebut; e) motivasi (Ruslin Lutan, 1988: 360), motivasi merupakan salah satu yang mempengaruhi kemampuan seseorang untuk mengatasi tantangan pada kegiatan sehingga akan membangkitkan keinginan berprestasi; f) jenis kelamin (Ruslin Lutan, 1988: 349), menyatakan terjadinya perbedaan dalam penampilan motorik anak laki-laki dan perempuan, dilihat anak laki-laki lebih kuat dalam melakukan gerakan dibandingkan dengan anak perempuan.

Hasil wawancara pada kepala sekolah dan guru kelompok A adalah pembelajaran motorik kasar yang dilakukan pada kegiatan di kelas lebih dominan mengembangkan motorik halus seperti, menulis, menggunting, menempel, dan sebagainnya. Kegiatan motorik kasar yang dilakukan di luar kelas antara lain senam yang dilakukan sebelum dimulainya pembelajaran dalam kelas, serta bermain bebas ketika jam istirahat. Peningkatan kemampuan motorik kasar anak usia 4-5 tahun dapat dilakukan dengan salah satunya melalui permainan. Permainan Finding A Star merupakan kegiatan motorik kasar dalam bentuk permainan yang bervariasi, menari, menyenangkan, dan dikreasikan dengan aktivitas berangkai, seperti: melompati tali, berlari zig-zag, melewati papan titian, engklek dengan bertujuan untuk melatih kekuatan, kelincahan, kelentukan, ketepatan, dan keseimbangan. Tujuan dari penelitian ini adalah mendeskripsikan penerapan permainan Finding A Star untuk meningkatkan kemampuan motorik anak usia dini pada kelompok A di TK PGRI 03 Tumpang Malang melalui permainan Finding A Star.

\section{Metode}

Penelitian ini menggunakan rancangan penelitian tindakan kelas (PTK) yang dikembangkan oleh Kurt (Arikunto 2014:42). Penelitian ini dilakukan selama dua siklus, setiap siklusnya dilakukan sebanyak dua kali pertemuan yang terdiri dari perencanaan, pelaksanaan, pengamatan, dan refleksi. Subyek dalam penelitian ini adalah anak usia 4-5 tahun kelompok A TK PGRI 03 Tumpang dengan jumlah 8 anak, yang terdiri 6 anak laki-laki dan 2 anak perempuan. Data yang akan diambil dalam penelitian ini yaitu mengenai data proses dan hasil pembelajaran dengan penerapan permainan Finding A Star yang mencakup unsur motorik kasar berupa kekuatan, kelincahan, kelentukan, ketepatan, dan keseimbangan.

Teknik pengumpulan data yang digunakan yaitu observasi, wawancara, dan dokumentasi. Instrumen penelitiannya berupa lembar observasi, catatan lapangan, lembar wawancara, dan dokumen. Analisis data pada penelitian tindakan kelas ini adalah kualitatif 
dan kuantitatif. Penelitian ini dikatakan tercapai meningkatkan pembelajaran fisik motorik kasar anak jika persentase kelas lebih dari 70\%. Sebaliknya jika persentase kelas kurang dari $70 \%$ maka penelitian ini belum tercapai.

\section{Hasil dan Pembahasan}

Kegiatan pratindakan ini dilaksanakan pada bulan januari 2019 di TK PGRI 03 Tumpang pada kelompok A tahun ajaran 2018/2019. Berdasarkan hasil pengamatan bahwa keterampilan motorik kasar anak berupa unsur kekuatan, kelincahan, kelentukan, ketepatan, dan keseimbangan pada kelompok A di TK PGRI 03 Tumpang belum berkembang secara optimal. Hasil analisis dari pratindakan pada kemampuan motorik kasar anak masih ada 6 dari 8 anak yang belum optimal untuk unsur kekuatan, 5 dari 8 anak belum berkembang secara optimal untuk unsur kelincahan, 6 dari 8 anak yang belum berkembang secara optimal untuk unsur kelentukan, 6 dari 8 anak yang belum optimal dalam unsur ketepatan, 5 dari 8 anak belum berkembang secara optimal dalam unsur keseimbangan. Kriteria ketercapaian kelas yang belum tercapai dengan presentase unsur kekuatan, kelentukan, ketepatan $25 \%$ dan unsur kelincahan, keseimbangan 37,5\%. Fakta dari data pratindakan tersebut membuktikan bahwa diperlukannya tindakan untuk meningkatkan kemampuan motorik kasar anak.

Pelaksanaanya kegiatan pada siklus I dilaksanakan sebanyak 2 kali pertemuan yaitu dari hari Selasa tanggal 16 April 2019 dan hari Kamis 18 April 2019 yang bertempat di TK PGRI 03 Tumpang. Berdasarkan penerapan permainan Finding A Star pada siklus I bahwa kemampuan motorik kasar anak berupa indikator kekuatan dengan jumlah 5 anak mencapai presentase 37,5\%; kelincahan dengan jumlah 4 anak mencapai presentase 50\%; kelentukan dengan jumlah 4 anak mencapai presentase 50\%, ketepatan dengan jumlah 3 anak mencapai presentase 37,5\%; keseimbangan dengan jumlah 3 anak mencapai presentase $37,5 \%$. Berdasarkan hasil keseluruhan ketercapaian kelas pada siklus I dalam penerapan permainan Finding A Star peneliti memilih hasil yang terbaik dari pelaksanaan, namun dalam penerapan permainan Finding A Star belum tercapai untuk meningkatkan kemampuan motorik kasar anak. Oelh sebab itu, peneliti melanjutkan penelitian pada siklus II dengan adanya perbaikan.

Kelebihan permainan Finding A Star pada siklus I ini adalah anak senang dan tertarik pada kegiatan permainan Finding A Star dan pembelajaran diluar kelas, karena dapat memberikan suasana baru untuk anak. Kelemahan permianan Finding A Star pada siklus I adalah (1) memperhatikan alur permainan dan mempertimbangkan konsistensi gerakan, (2) penambahan alas untuk kegiatan pada unsur kelentukan, (3) kurangnya mengkondisikan anak-anak pada kegiatan permainan berlangsung.

Berdasarkan kelemahan-kelemahan tersebut perlu adanya perbaikan pada pelaksanaan siklus selanjutnya. Perbaikan yang harus dilakukan adalah (1) peneliti bekerja sama dengan guru untuk memberikan penguatan kepada anak agar anak lebih dapat memahami perbedaan aktivitas gerak lompat dan loncat, (2) menambahkan alas yang lebar untuk kegiatan pada unsur kelentukan, (3) peneliti dan guru bekerja sama untuk mengkondisikan anak-anak pada kegiatan permainan berlangsung agar kondusif.

Pelaksanaanya kegiatan siklus II dilaksanakan sebanyak 2 kali pertemuan yaitu pada hari Selasa 23 April 2019 dan hari Kamis tanggal 25 April 2019 yang bertempat di TK PGRI 03 Tumpang. Siklus II dilaksanakan karena kriteria ketercapaian belajar dengan penerapan permainan Finding A Star belum tercapai untuk meningkatkan kemampuan motorik kasar anak pada siklus I. Pelaksanaan siklus II merupakan hasil perbaikan dari siklus I dengan 
kelebihannya akan tetap dipertahankan, namun untuk kelemahan akan diperbaiki. Peneliti melakukan perbaikan pada penguatan dalam aktivitas gerak melompat dan loncat, serta menambahkan alas agak lebar agar anak mudah untuk melakukan kegiatan pada unsur kelentukan dan lebih mengkondisikan anak-anak ketika kegiatan berlangsung.

Berdasarkan penerapan permainan Finding A Star pada siklus II kemampuan motorik anak berupa indikator kekuatan dengan jumlah 6 anak mencapai 75\%; kelincahan dengan jumlah 8 anak mencapai presentase 100\%, kelentukan dengan jumlah 7 anak mencapai presentase 87,5\%; ketepatan dengan jumlah 7 anak mencapai presentase 87,5\%; keseimbangan dengan jumlah 6 anak mencapai presentase 75\%. Berdasarkan hasil keseluruhan ketercapaian kelas pada siklus II dalam penerapan permainan Finding A Star peneliti memilih hasil yang terbaik dari pelaksanaan. Oleh karena itu, penerapan permainan Finding A Star mampu meningkatkan kemampuan motorik kasar anak dan penelitian ini berakhir pada siklus II dengan kriteria keberhasilan tercapai.

Peningkatan kemampuan motorik kasar anak terlihat dari pratindakan hingga pelaksanaan siklus II. Pada pelaksanaanya di pratindakan dengan indikator kekuatan mencapai persentase $25 \%$, aspek kelincahan mencapai 37,5\%, aspek kelentukan mencapai $25 \%$, aspek ketepatan mencapai 25\%, aspek keseimbangan mencapai 37,5\%. Pelaksanaan pada siklus I pada aspek kekuatan mencapai persentase 37,5\%, aspek kelincahan 50\%, aspek kelentukan mencapai 50\%, aspek ketepatan mencapai 37,5\%, aspek keseimbangan mencapai 37,5\%. Peningkatan pada pelaksanaan siklus II dengan aspek kekuatan mencapai 75\%, aspek kelincahan mencapai $100 \%$, aspek kelentukan $87,5 \%$, aspek ketepatan mencapai 87,5\%, aspek keseimbangan mencapai 75\%. Hasil analisis data pada penelitian siklus I dapat dilihat bahwa kriteria ketercapaian belajar belum tercapai dalam meningkatkan kemampuan motorik kasar anak melalui permainan Finding A Star. Pada pelaksanaan siklus II dapat dilihat bahwa kriteria ketercapaian belajar tercapai melalui permainan Finding A Star. peningkatan kemampuan motorik kasar anak melalui permainan Finding A Star anak mampu melakukan aktivitas motorik kasar anak pada indikator kekuatan, kelincahan, kelentukan, ketepatan, keseimbangan. Berdasarkan pemaparan hasil pelaksanaan permainan Finding A Star bahwa kemampuan motorik kasar anak terbukti meningkat dengan kategori tercapai.

Penerapan permainan Finding A Star pada kelompok A TK PGRI 03 Tumpang di luar kelas. Permainan Finding A Star merupakan salah satu permainan yang menarik bagi anak dan dapat memotivasi minat anak karena anak dapat melakukan gerakan yang melatih kemampuan motorik kasar dan mampu menarik semangat anak dan minat anak untuk melakukan kegiatan permainan. Upaya yang dapat dilakukan dalam mengembangkan perkembangan motorik anak usia dini antara lain meningkatkan aktivitas bermain anak, dan meningktakan kebugaran jasmani anak dengan menyesuaikan tahapan pertumbuhan dan perkembangan anak (Yudanto, 2006:39).

Permainan Finding A Star memiliki kegiatan berangkai yang mana setiap anak harus melakukan semua rangkaian kegiatan yang telah dipersiapkan. Setiap kegiatan dalam permainan ini mengandung unsur pemeblajaran motorik kasar. hal ini sesuai dengan hasil pengembangan dari Karimah (2014) bahwa permainan Finding A Star aman untuk dilakukan. Pada kegiatan I aktivitas anak berlari zig-zag, tujuannya untuk melatih kelincahan anak. Pada aktivitas II anak melompati tali untuk melatih kekuatan otot anak. Pada aktivitas III anak membungkukkan badan dengan kaki lurus, untuk mengambil bintang berwarna kegiatan ini 
dilakukan untuk melatih kelentukan. Pada kegiatan IV anak melewati papan titian untuk melatih keseimbangan anak. Pada kegiatan V melemepar bola tepat dengan sasarn dan diberikan kesempatan $3 \mathrm{x}$ apabila lemparan pertama dan kedua gagal, kegiatan ini untuk melatih keseimbangan anak.

Pada siklus I anak antusias dalm pembelajaran saat diajak untuk melakukan kegiatan permainan Finding A Star, anak merasa senang karena melakukan permainan Finding A Star di luar kelas dengan memberikan suasan baru kepada anak. Kelemahan yang terjadi pada siklus I ini antara lain: (1) memperhatikan alur permainan dan mempertimbangkan konsistensi gerakan, (2) penambahan alas untuk kegiatan pada unsur kelentukan, (3) kurangnya mengkondisikan anak-anak pada kegiatan permainan berlangsung,. Pada siklus II anak lebih semangat dan senang dalam emlakukan permainan Finding A Star. kegiatan ini berjalan dengan baik dan sesuai dengan rencana pelaksanaan yang telah disusun oleh peneliti. Perbaikan dari pelaksanaan siklus I membuat anak lebih memahami dari gerak aktivitas melompat dan loncat dan memberikan alasa yang sedikit lebih besar pada kegiatan kelentukan. Perbaikan alur permainan Finding A Star anak semakin mudah melakukan kegiatan permainan Finding A Star, lebih semangat dan melakukannya sesuai dengan indikator. Pada pelaksanaan siklus II telah sesuai dengan kriteria ketercapaian kelas dengan kategori tercapai sehingga peneliti menghentikan penelitian pada siklus II.

Penerapan permainan Finding A Star pada proses pembelajaran dapat meningkatkan kemampuan motorik kasar anak. Peningkatan kemampuan motorik kasar anak pada permainan Finding A Star meliputi kekuatan ketika melompati tali, kelincahan ketika berlari zig-zag, kelentukan ketika membungkukkan badan dengan kaki lurus, ketepatan ketika melempar bola tepat dengan sasaran, dan keseimbangan ketika melewati papan titian. Meningkatkan kemampuan motorik kasar anak mengajarkan anak untuk bekerja sama, kejujuran, dan memberikan kesenangan tersendiri pada anak (Hidayati, 2013:200). Peningkatan kemampuan motorik kasar anak dapat diketahui melalui pratindakan, siklus I dan siklus II. Pada pratindakan kemampuan motorik kasar anak belum tercapai pada kriteria ketercapaian kelas, indikator kekuatan dengan jumlah 2 anak mencapai presentase 25\%, kelincahan 3 anak mencapai presentase 37,5\%, kelentukan dengan jumlah 2 anak mencapai presentase $25 \%$, ketepatan dengan jumlah 2 anak mencapai presentase $25 \%$, keseimbangan dengan jumlah 3 anak mencapai presentase $37,5 \%$.

Pada siklus I kemampuan motorik kasar anak dengan penerapan permainan Finding A Star belum tercapai pada kriteria ketercapaian kelas. Berdasarkan pelaksanaannya permainanan Finding A Star pada siklus I mendapatkan hasil hasil terbaik berupa indikator kekuatan dengan jumlah 5 anak mencapai presentase 37,5\%; kelincahan dengan jumlah 4 anak mencapai presentase 50\%; kelentukan dengan jumlah 4 anak mencapai presentase $50 \%$, ketepatan dengan jumlah 3 anak mencapai presentase 37,5\%; keseimbangan dengan jumlah 3 anak mencapai presentase 37,5\%. Pada penerapan permainan Finding A Star pada siklus I ini belum mampu meningkatkan kemampuan motorik kasar anak, sehingga peneliti melanjutkan penelitian pada siklus II agar mencapai hasil yang sesuai.

Pada pelaksanaan siklus II kemampuan motorik kasar anak dengan penerapan permainan Finding A Star mengalami peningkatan dari pada siklus I dengan kriteria ketercapaian kelas tercapai. Sesuai dengan hal tersebut, bahwa permainan dapat digunakan untuk mengukur ekmampuan dan potensi anak (Mutiah, 2010:113). Presentase ketercapaian 
kelas pada siklus II dengan penerapan permainan Finding A Star berupa indikator kekuatan dengan jumlah 6 anak mencapai 75\%; kelincahan dengan jumlah 8 anak mencapai presentase 100\%, kelentukan dengan jumlah 7 anak mencapai presentase 87,5\%; ketepatan dengan jumlah 7 anak mencapai presentase 87,5\%; keseimbangan dengan jumlah 6 anak mencapai presentase $75 \%$. Berdasarkan data yang telah diperoleh bahwa kemampuan motorik kasar anak mengalami peningkatan melalui permainan Finding A Star pada kategori tercapai, amaka peneliti menghentikan penelitiannya pada siklus II.

\section{Simpulan}

Berdasarkan hasil penelitian tindakan kelas yang telah dilaksanakan dan pembahasan yang telah dipaparkan, dapat diperoleh eksimpulan sebagai berikut: (1) penerapan permainan Finding A Star di TK PGRI 03 Tumpang dilaksanakan di luar kelas. Permaian Finding A Star menggunakan media yang aman untuk anak. Permainan Finding A Star merupakan kegiatan motorik kasar dalam bentuk permainan yang memiliki aktivitas bervariasi, menyenangkan, menarik, dan dikreasikan dengan aktiviats berlari zig-zag, melompati tali, membungkukkan badan dengan kaki lurus untuk mengambil bintang berwarna, melewati papan titian, melempar bola tepat dengan sasaran. Yang bertujuan untuk melatih kekuatan, kelincahan, kelentukan, ketepatan dan keseimbangan. (2) peningkatan kemampuan motorik kasar anak usia dini pada kelompok A di TK PGRI 03 Tumpang terbukti pada hasil penelitian tindakan kelas menunjukkan pencapaian indikator kekuatan, kelincahan, kelentukan, ketepatan, dan keseimbangan. Terbukti hasil peningkatan dari pratindakan sampai dengan pelaksanaan pada siklus II dari kriteria belum tercapai sehingga memiliki kriteria tercapai. Peningkatan mencapai $62,5 \%$ dengan indikator kekuatan, indikator kelincahan mencapai 87,5\%, kelentukan mencapai 62,5\%, ketepatan mencapai 75\%, keseimbangan mencapai 75\%. Peningkatan yang terjadi terhitung dari pelaksanaan pratindakan sampai dengan pelaksanaan siklus II yang mengalami peningkatan.

Berdasarkan hasil dan kesimpulan selama penelitian berlangsung di TK PGRI 03 Tumpang, peneliti memberikan saran bagi sekolah untuk menunjang keberhasilan ana untuk menyediakan media pembelajaran yang lebih menarik dan efektif untuk terselenggaranya proses pembelajaran. Bagi peneliti lain sebaiknya mampu menciptakan media pembelajaran yang menarik dan mampu mengembangkan serta meningkatkan aspek perkembangan anak melalui permainan yang lainnya.

\section{Daftar Rujukan}

Arikunto, S. (2014). Prosedur Penelitian. Jakarta: Rineka Cipta.

Hidayati, M. (2013). Peningkatan Kemampuan Motorik Kasar Anak Melalui Permainan Bakiak. Jurnal Pendidikan Anak Usia Dini. 7(1), 195-200.

Hurlock, E. B. (1978). Perkembangan Anak. Jakarta: Erlangga.

Mutiah, D. (2010). Psikologi Bermain Anak Usia Dini. Jakarta: Prenada Media Group.

Yudanto. (2006). Upaya Mengembangkan Kemampuan Motorik Anak Prasekolah. Jurnal Pendidikan Jasmani Indonesia, 3(3), 31-39. 